\title{
PENGEMBANGAN E-LKPD BERBASIS KEMAMPUAN BERPIKIR TINGKAT TINGGI MATA PELAJARAN TEMATIK KELAS IV SEKOLAH DASAR
}

\author{
K.S.P. Wahyuni ${ }^{1}$, I.M. Candiasa ${ }^{2}$, I.M.C. Wibawa ${ }^{3}$ \\ ${ }^{123}$ Program Studi Pendidikan Dasar \\ Universitas Pendidikan Ganesha \\ Denpasar, Indonesia \\ e-mail: sri.puji@undiksha.ac.id ${ }^{1}, \underline{\text { made.candiasa@undiksha.ac.id }}^{2}$, \\ madecitra.wibawa@undiksha.ac.id ${ }^{3}$
}

\begin{abstract}
Abstrak
Penelitian ini bertujuan untuk mengembangkan E-LKPD Berbasis Kemampuan Berpikir Tingkat Tinggi pada siswa kelas Kelas IV Sekolah Dasar. Penelitian ini menggunakan model pengembangan ADDIE yang terdiri dari 5 fase, yaitu analyze (analisis), design (rancangan), development (pengembangan), implementation (implementasi) dan evaluation (evaluasi). Namun pada pelaksanaannya hanya sampai pada fase implementasi yang dilakukan secara daring. Subjek penelitian ini sebanyak 16 orang yang terdiri dari 3 akademisi, 3 guru kelas IV dan 10 siswa kelas IV. Instrumen yang digunakan dalam penelitian ini ada 5, yaitu: lembar penilaian materi pelajaran dalam LKPD, lembar penilaian materi LKPD dari LORI, lembar penilaian media pembelajaran LORI, kuesioner kepraktisan dan tes hasil belajar. Data yang diperoleh dianalisis dengan formula Gregory dan menghitung rata-rata nilai dari ahli, guru dan siswa. Hasil penelitian menunjukan a) karakteristiks e-LKPD mencakup 5 bagian, yaitu : komponen, tampilan, materi, aktivitas pembelajaran dan sistem penilaiannya, b) e-LKPD yang dikembangkan bersifat sangat valid baik dari segi materi dengan skor $(4,69)$ maupun sebagai media pembelajaran dengan skor $(4,78)$, c) e-LKPD terkategori sangat praktis dengan skor 4,51 dan d) e-LKPD yang dikembangkan efektif menghasilkan nilai rata-rata 83,67 dengan ketuntasan $90 \%$.
\end{abstract}

Kata Kunci : e-LKPD; Kemampuan Berpikir Tingkat Tinggi; Mata Pelajaran Tematik

\begin{abstract}
This research aims at developing elektronic students' worksheet based on higher order thinking skill for forth grade students in elementary school. This research applied ADDIE model consisting of 5 stages, namely : analyze, design, development, implementation and evaluation. However, this research was finished in implementation stage which was done in online learning. The subjects of this research were 10 people,consisting of 3 experts, 3 forth grade teachers and 10 forth grade students. There were 5 instrumens used, namely : assessment sheet for learning material in elektronic students' worksheet, assessment sheet for elektronic students' worksheet materials by LORI, assessment sheet for elektronic students' worksheet media by LORI, questionaire for practicality test and learning achievement test. The obtained data were analyzed by Gregory formula and mean from experts, teachers, and students. The analysis shows a) electronic students' worksheet is seen from 5 parts, namely: components, face, materials, learning activity,and assessment, b) electronic students' worksheet is valid viewed form the materials with scoore of 4,69 and media with score of $4,78, c)$ electronic students' worksheet is categorized into very practical with score of 4,51 and d) electronic students' worksheet is efective because it makes stduents' mean score of 83,67 and classical mastery of $90 \%$.
\end{abstract}

Keywords : Electronic Students' Worksheet; HOTS; Thematic Lesson 


\section{PENDAHULUAN}

Mempersiapkan sumber daya manusia (SDM) yang berdaya saing tinggi mutlak harus dilakukan setiap negara agar dapat memenangkan persaingan di abad 21 ini. SDM yang tidak unggul tentu akan kalah dalam persaingan. Dampaknya tentu pada kelangsungan suatu bangsa dan daya saingnya dalam kehidupan. Untuk itu, setiap negara harus siap berbenah agar SDM yang dimiliki semakin membaik. Pembenahan harus dilakukan di semua sendi dan lini kehidupan termasuk pada sektor-sektor vital seperti pendidikan.

Pada hakikatnya, pendidikan adalah suatu proses dalam rangka mempengaruhi peserta didik agar dapat menyesuaikan diri sebaik mungkin terhadap lingkungan dan dengan demikian akan menimbulkan perubahan dalam dirinya yang memungkinkannya untuk berfungsi secara kuat dalam kehidupan masyarakat (Hamalik, 2001: 79). Ini berarti pendidikan harus bisa menyiapkan bekal untuk peserta didik untuk menghadapi kondisi seperti saat ini. Jika pendidikan gagal menjalankan tugasny, ini berarti juga kegagalan dalam kehidupan peserta didik.

Usaha peningkatan mutu pendidikan terus dilakukan oleh pemerintah untuk meningkatkan kualitas SDM di negara ini. Salah satunya dengan perubahan kurikulum yang semakin mutahir. Salah satunya adalah Kurikulum 2013 revisi 2017. Esensi dasarnya adalah perubahan tujuan pembelajaran menuju keterampilan berpikir tingkat tinggi atau higher order thinking skill (HOTS). Keterampilan ini mutlak diperlukan karena pada revolusi industri 4.0 dibutuhkan keterampilan yang kritis dan kreatif sebagai solusi dari permasalahan yang semakin kompleks.

Kemampuan berpikir tingkat tinggi atau HOTS (high order thinking skills) merupakan suatu kemampuan yang harus ada di dalam diri peserta didik (Dinni, 2018). Kemampuan ini bukan lagi fokus pada hal-hal yang sifatnya hafalan. HOTS merupakan kemampuan peserta didik dalam memecahkan suatu permasalahan dimana permasalahan tersebut tidak ada langkah-langkah penyelesaiannya yang telah diajarkan, yang memerlukan penjelasan mengenai langkah-langkah tersebut dan mempunyai banyak solusi penyelesaian yang akan terjadi. Ini berarti siswa diarahkan untuk berpikir pemecahan masalah.

Agar menghasilkan output berupa siswa yang memiliki HOTS maka peran guru sangat krusial. Mereka harus menyiapkan segala sesuatunya untuk menunjang proses pembelajaran. salah satunya adalah lembar kerja peserta didik. Lembar kegiatan siswa dimaksudkan untuk mengaktifkan siswa, membantu siswa menemukan dan mengembangkan konsep, melatih siswa menemukan konsep, menjadi alternatif cara penyajian materi pelajaran yang menekankan keaktifan siswa serta dapat memotivasi siswa (Trianto, 2010: 212).

LKPD merupakan salah satu sumber belajar yang diperkenalkan pada kurikulum 2013. Sebelumnya LKPD dikenal dengan LKS (lembar kerja siswa). LKPD digunakan untuk membantu para guru dalam melatih keterampilan siswa dalam menemukan konsep-konsep melalui langkah kerja maupun permasalahan yang disediakan dan dilengkapi dengan penyelesaian. Siswa dapat dilatih untuk dapat memecahkan permasalahan-permasalahan yang berkaitan dengan materi pelajaran. Selain itu, siswa juga mendapatkan panduan belajar secara praktis karena LKPD berisi langkah-langkah pembelajaran yang harus dilakukan oleh siswa. Dengan demikian, muaranya adalah hasil belajar siswa yang optimal.

LKPD merupakan salah satu bahan ajar yang berperan penting dalam memberikan penugasan yang relevan dengan materi yang diajarkan. Hal ini didukung oleh penelitian Musfiqi dan Jailani (2014: 57) yang mengemukakan bahwa bahan ajar hasil pengembangan berupa LKPD dan RPP dinyatakan efektif untuk meningkatkan karakter dan Higher Order Thinking Skill (HOTS). Hal yang sama juga ditemukan orlah Nurjanah, Arcana dan Rhosyida (2019) yang mengemukakan bahwa LKPD efektif dalam meningkatkan keterampilan berpikir kritis siswa kelas V. Dengan demikian 
dapat disimpulkan sementara bahwa dengan penggunaan LKPD dalam pembelajaran dapat meningkatkan hasil belajar peserta didik.

Namun pada kenyataannya, harapan akan kualitas SDM yang baik masih jauh dari harapan. Berdasarkan hasil PISA 2018, nilai untuk Membaca, Matematika, dan Sains dari hasil tes di 2018 adalah 371,379 , dan 396. Nilai ini mengalami penurunan dibanding tes di tahun 2015, di mana berturut-turut Membaca, Matematika, dan Sains kita meraih skor 397, 386, 403. Pada kategori kemampuan membaca, Indonesia menempati peringkat ke-6 dari bawah (74). Lalu pada kategori matematika, Indonesia berada di peringkat ke-7 dari bawah (73). Sementara pada kategori kinerja sains, Indonesia berada di peringkat ke-9 dari bawah (71).

Lebih lanjut, berdasarkan hasil pengamatan di Gugus 06 Marga, ada beberapa permasalahan teridentifikasi. Pertama, guru belum siap dengan tuntutan pembelajaran berbasis HOTS. Kedua, semua guru masih berpatokan pada buku dalam mengajar. Belum banyak guru kreatif merancang perangkat pembelajaran, seperti LKPD. Ketiga, guru belum mampu memanfaatkan kemajuan teknologi untuk menunjang proses pembelajaran. Keempat, proses pembelajaran yang dilakukan masih belum menunjukan ada upaya ke arah pembelajaran berbasis HOTS. Kelima, latihan soal yang diberikan kepada siswa juga hanya baru sebatas tingkatan kognitif mengingat (C1), memahami (C2) dan mengaplikasikan (C3). Keenam, guru belum memiliki LKPD elektronik (e-LKPD) yang berorientasi kemampuan berpikir tingkat tinggi.

Lebih lanjut dilakukan wawancara dengan guru-guru kelas IV di Gugus 06 Marga. Wawancara dilakukan secara online via Whatsap pada tanggal 4 Juni 2020. Hasil wawancara menunjukan bahwa pembelajaran dengan daring sulit dilaksanakan. Permasalahan utama yang dihadapi adalah media pembelajaran yang membuat siswa dapat belajar dengan menyenangkan. Selama pandemi, pembelajaran hanya mengandalkan buku paket dari pemerintah dan latihan soalsoal. Padahal, jika mengacu pada keterangan para guru, 100 persen orang tua siswa memiliki $\mathrm{hp}$ android (smart phone). Ini menunjukan bahwa peluang untuk menciptakan pembelajaran berbasis daring yang efektif dan menarik sangat baik.

Berdasarkan fenomena tersebut, pengembangan e-LKPD berorientasi kemampuan berpikir tingkat tinggi penting dilakukan sebagai upaya menciptakan proses pembelajaran daring yang berkualitas. Dengan menggunakan LKPD berbasis elektronik, tentu pembelajaran lebih menarik bagi siswa dan mereka dapat mengaksesnya melalui smart phone milik orang tua mereka. Dengan menggunakan fitur-fitur yang ada dalam dunia digital, LKPD dapat dibuat seideal mungkin sesuai kebutuhan peserta didik dan tuntutan jaman.

Pengembangan e-LKPD berorientasi kemampuan berpikir tingkat tinggi dapat menciptakan proses pembelajaran yang sesuai abad 21 dan memfasilitasi siswa dalam melatih kemampuan berpikir tingkat tingginya. Melalui langkah-langkah dan petunjuk yang ada dalam e-LKPD tentu siswa diarahkan untuk mengikuti pembelajaran dan menyelesaikan soalsoal latihan yang diberikan dengan baik. Dalam mengerjakan soal, siswa juga dapat langsung menjawab pada lembar worksheet yang tersedia, ketika selesai tinggal mengklik tanda yang ada. Siswa secara langsung dapat mengetahui jawaban dan skornya. Hal ini tentunya membawa keuntungan bagi siswa karena dapat secara cepat mengetahui jawabannya apakah benar atau salah.

Penggunaan e-LKPD juga dapat memberikan dampak positif bagi hasil belajar siswa terutama pada saat pandemi seperti saat ini. Penggunaan LKPD sebagai alat untuk membantu siswa dalam proses belajar, karena di dalamnya terdapat materi yakni ringkasan dari berbagai sumber buku yang relevan sehingga proses pembelajaran efektif pada waktu yang dibutuhkan yang mana didalamnya terdapat beberapa materi pembelajaran dan latihan soal serta petunjuk kegiatan pembelajaran (Dewi dan 
Susilowibowo, 2016). Dengan demikian, siswa diarahkan belajar efektif dan hasil belajarnya juga menjadi baik.

Ada beberapa hasil penelitian yang menunjukan efektivitas penggunaan LKPD terhadap hasil belajar siswa. Hasil penelitian yang dilakukan oleh Purwasi dan Fitriana (2020) menunjukan bahwa terjadi peningkatan hasil belajar matematika siswa setelah diterapkan LKPD berbasis HOTS pada siswa. Hal senada juga ditemukan oleh Teti dan Hamdu (2018). Hasil penelitian ini menunjukan bahwa LKPD yang dikembangkan dapat meningkatkan pemahaman materi belajar siswa yang mencakup mata pelajaran IPA, Bahasa Indonesia, PJOK dan IPS. Hasil ujicoba yang dilakukan sebanyak dua kali menunjukan bahwa $81,3 \%$ siswa memahami materi dan meningkat menjadi rata-rata $95 \%$ siswa memahami isi pelajaran.

Dalam penelitian ini, e-LKPD yang dikembangkan memiliki empat karakteristiks. Pertama, LKPD disusun sesuai tingkat kecerdasan intelektual peserta didik kelas IV. Kedua, LKPD menekankan aktivitas pembelajaran yang berbasis saintifik sehingga mampu memfasilitasi HOTS. Ketiga, menggunakan aplikasi digital yang mampu membuat tampilan e-LKPD menjadi menarik. Keempat, latihan soal yang digunakan bersifat interaktif dan sesuai HOTS.

\section{METODE}

Penelitian ini merupakan penelitian pengembangan dengan model ADDIE dengan 5 fase, yaitu: analysis (analisa), design (rancangan), development (pengembangan), implementatian (penerapan), evaluation (evaluasi). Namun dalam penerapannya hanya sampai pada tahap implementasi yang dilakukan secara daring. Subjek penelitian ini berjumlah 16 orang. Mereka terdiri dari 3 dosen ahli, 3 guru kelas IV dan 10 siswa kelas IV. 5, yaitu: lembar penilaian materi pelajaran dalam LKPD, lembar penilaian materi LKPD dari LORI, lembar penilaian media pembelajaran LORI, kuesioner kepraktisan dan tes hasil belajar. Data yang diperoleh dianalisis dengan formula Gregory dan menghitung rata-rata nilai dari ahli, guru dan siswa. Nilai rata-rata kemudian dikonfirmasi ke dalam skala sebagai berikut.

Tabel 1. Skala Kategori Validitas

\begin{tabular}{cl}
\hline Nilai & \multicolumn{1}{c}{ Kategori } \\
\hline $3,50 \leq R v \leq 4,00$ & Sangat Valid \\
$2,50 \leq R v \leq 3,50$ & Valid \\
$1,50 \leq R v \leq 2,50$ & Tidak Valid \\
$1,00 \leq R v \leq 1,50$ & Sangat tidak Valid \\
\hline
\end{tabular}

Tabel 2. Skala Kategori Kepraktisan

\begin{tabular}{|c|c|}
\hline Nilai & Kategori \\
\hline $3,50 \leq R k \leq 4,00$ & $\begin{array}{l}\text { Sangat Praktis } \\
\text { layak }\end{array}$ \\
\hline $2,50 \leq R k \leq 3,50$ & Praktis/layak \\
\hline $1,50 \leq R k \leq 2,50$ & $\begin{array}{l}\text { Tidak praktis/tidak } \\
\text { layak }\end{array}$ \\
\hline $1,00 \leq R k \leq 1,50$ & $\begin{array}{ll}\text { Sangat } & \text { tidak } \\
\text { praktis/sangat } & \text { tidak } \\
\text { layak } & \end{array}$ \\
\hline
\end{tabular}

\section{HASIL DAN PEMBAHASAN}

Hasil penelitian dan pembahasannya dapat dibagi 4 bagian sesuai dengan jumlah rumusan masalah. Secara rinci dapat disajikan sebagai berikut.

\section{Karakteristiks E-LKPD berbasis HOTS}

Karakteristik e-LKPD berbasis HOTS yang dikembangkan mengacu pada komponen-komponen LKPD, aktivitas pembelajaran penunjang HOTS, sistem penilaian peunjang HOTS dan karakteristiks anak sekolah dasar. Hal itu sudah direalisasikan dalam e-LKPD. Karakteristik ini menunjukan bahwa eLKPD sesuai dengan kebutuhan di lapangan. Karakteristiknya dapat dibagi menjadi 5 bagian, yaitu : komponen, tampilan, materi, aktivitas pembelajaran dan sistem penilaiannya.

Komponen-komponen yang ada dalam e-LKPD dibuat sesuai dengan kajian teori. Yunitasari (2013: 10) mengemukakan unsur yang ada dalam LKPD meliputi (1) judul, (2) petunjuk belajar, (3) indikator pembelajaran, (4) informasi pendukung, (5) langkah kerja, serta (6) penilaian. Unsur-unsur tersebut 
sudah semuanya ada dalam e-LKPD berbasis HOTS yang dikembangkan. Judul memberikan identitas tentang fokus materi dalam e-LKPD sehingga dalam penerpannya guru tidak mengalami kesulitan.

Dilihat pada tampilannya, e-LKPD dibuat berwarna-warni, gambar-gambar pendukung dan video pengantar materi pembelajaran. Menurut Darmodjo dan Kaligis (1993), e-LKPD harus dibuat menarik agar siswa juga tertarik menggunakannya. E-LKPD harus merupakan kombinasi gambar, video dan kata-kata. Dalam e-LKPD tentu tidak boleh hanya deretan kata-kata dan langsung pertanyaan atau sebaliknya dengan gambar-gambar. Lebih lanjut, perpaduan video, gambar dan kata-kata dengan layout yang berwarna-warni memberikan kesan variatif dalam e-LKPD (Indriyani, 2013).

Hal yang penting dalam e-LKPD adalah materi yang disampaikan. Materi dalam e-LKPD dibuat sesuai dengan tuntutan Kurikulum 2013 edisi revisi 2017. Pemilihan materi diawali dengan menganalisis kompetensi dasar. Dari kompetensi dasarini selanjutnya direalisasikan dalam bentuk indikator pembelajaran (Suyanto, dkk, 2011). Materi pembelajaran disajikan secara tematik karena e-LKPD dibuat untuk keperluan siswa sekolah dasar.

Dalam aktivitas pembelajaran, siswa diarahkan untuk memiliki keterampilan berpikir tingkat tinggi. Sesuai dengan Kurikulum 2013 maka pendekatan pembejaran yang digunakan adalah pendekatan saintifik. Kegiatan pembelajaran mencakup 5 langkah, yaitu : mengamati, menanya, mengumpulkan informasi, mengolah informasi dan menarik kesimpulan (Kemendikbud, 2014). Penerapan pendekatan saintifik dapat meningkatkan kemampuan berpikir peserta didik, membentuk kemampuan dalam menyelesaikan masalah secara sistematik, menciptakan kondisi pembelajaran supaya peserta didik merasa bahwa belajar merupakan suatu kebutuhan, melatih peserta didik dalam mengemukakan ide-ide, meningkatkan hasil belajar peserta didik, dan mengembangkan karakter peserta didik (Hosnan, 2014).

Komponen terakhir dalam e-LKPD adalah sistem penilaian. Sudijono (2009) menyatakan penilaian dalam pendidikan adalah tahapan untuk menilai hasil belajar. Pengembangan penilaian harus didasarkan pada tujuan pembelajaran. Mengingat target pengembangan adalah kemampuan berpikir tingkat tinngi maka sistem penilaian yang digunakan juga mengukur tingkat kognitif C4, C5 dan C6.

\section{Validitas E-LKPD berbasis HOTS}

Uji validitas e-LKPD dapat dibagi menjadi 2, materi dan media. Hasil uji materi dengan LORI dapat disajikan sebagai berikut.

Tabel 3. Hasil Uji Validasi Materi e-LKPD

\begin{tabular}{|c|c|c|c|}
\hline No. & Aspek & Nilai & Kategori \\
\hline 1. & Kualitas Isi & 4,75 & $\begin{array}{l}\text { Sangat } \\
\text { Layak }\end{array}$ \\
\hline 2. & $\begin{array}{l}\text { Tujuan } \\
\text { Pembelajaran }\end{array}$ & 4,5 & $\begin{array}{l}\text { Sangat } \\
\text { Layak }\end{array}$ \\
\hline 3. & $\begin{array}{l}\text { Umpan Balik } \\
\text { dan Adaptasi }\end{array}$ & 4,5 & $\begin{array}{l}\text { Sangat } \\
\text { Layak }\end{array}$ \\
\hline 4. & Motivasi & 5 & $\begin{array}{l}\text { Sangat } \\
\text { Layak }\end{array}$ \\
\hline \multicolumn{2}{|c|}{ Rata-rata } & 4,69 & $\begin{array}{l}\text { Sangat } \\
\text { Layak }\end{array}$ \\
\hline
\end{tabular}

Tabel 3 menunjukan bahwa nilai untuk aspek kualitas isi sebesar 4,75 dengan kategori sangat layak, aspek tujuan pembelajaran sebesar 4,5 dengan kategori sangat layak, aspek umpan balik dan adaptasi sebesar 4,5 dengan kategori sangat layak dan aspek motivasi sebesar 5 dengan kategori sangat layak. Dengan demikian, nilai rata-rata validitas isi materi dengan instrumen LORI sebesar 4,69 dengan kategori sangat layak. Ini berarti ditinjau dari validitas isi materi, e-LKPD yang dikembangkan terkategori sangat layak sehingga sangat layak digunakan.

$$
\text { Selanjutnya dilakukan analisis }
$$

validitas e-LKPD sebagai media pembelajaran. hasil analisis dapat disajikan sebagai berikut. 
Tabel 4. Hasil Uji Validasi Media

\begin{tabular}{|c|c|c|c|}
\hline No. & Aspek & Nilai & Kategori \\
\hline 1. & $\begin{array}{l}\text { Desain } \\
\text { Presentasi }\end{array}$ & 4,5 & Sangat Layak \\
\hline 2. & $\begin{array}{l}\text { Interaksi } \\
\text { Pengguna }\end{array}$ & 4,67 & Sangat Layak \\
\hline 3. & Aksebilitas & 4,75 & Sangat Layak \\
\hline & $\begin{array}{l}\text { Penggunaan } \\
\text { Kembali }\end{array}$ & 5 & Sangat Layak \\
\hline & $\begin{array}{l}\text { Memenuhi } \\
\text { standar }\end{array}$ & 5 & Sangat Layak \\
\hline \multicolumn{2}{|c|}{ Rata-rata } & 4,78 & Sangat Layak \\
\hline
\end{tabular}

Berdasarkan Tabel 4 maka dapat diketahui aspek desian mendapat nilai 4,5 dengan kategori sangat layak, aspek interaksi pengguna mendapat nilai 4,67 dengan kategori sangat layak, aspek aksebilitas mendapat nilai 4,75 dengan kategori sangat layak, aspek penggunaan kembali mendapat nilai 5 dengan kategori sangat layak dan aspek memenuhi standar mendapat nilai 5 dengan kategori sangat layak. Secara umum, nilai rata-rata aspek media adalah sebesar 4,78 dengan kategori sangat layak.

Hasil ini menunjukan bahwa e-LKPD sudah ideal sesuai dengan kriteria atau mengukur yang hendak diukur baik dari segi materi dan media pembelajaran (Suryabrata, 2000). Dari segi materi pelajaran yang terkandung dalam e-LKPD, Ada 10 materi yang teridentifikasi. Hasil perhitungan menunjukan semua ahli menyatakan semua materi relevan dengan tema dan isi e-LKPD. Ini berarti materi dalam e-LKPD layak digunakan dalam eLKPD mengingat validator sudah menyatakan valid (Ahmad dkk, 2018).

Validitas selanjutnya yang diukur adalah validitas isi e-LKPD. Ada empat aspek yang dinilai, yaitu: kualitas isi, tujuan pembelajaran, umpan balik dan motivasi. Kualitas isi e-LKPD terkategori sangat valid. Ini menunjukan materi yang ada didalamnya sudah sesuai dengan tuntutan kurikulum. Selain itu, keseimbangan ide-ide juga disusun dengan baik dengan memvariasikan penggunaan gambar, video dan kata-kata.

Tujuan pembelajaran juga terkategori sangat valid yang berarti sudah sesuai dengan tuntutan kurikulum. Dalam perumusan tujuan pembelajaran, sudah dilakukan secara hati-hati dan detail agar e-LKPD tepat sasaran. Aktivitas pembelajaran dirancang untuk memfasilitasi siswa mencapai HOTS. Hal ini direalisasikan dengan menggunakan pendekatan saintifik. Menurut Hosnan (2014), pendekatan saintifik memungkinkan siswa aktif mengkonstruksi pengethuannya, melatih kemampuan berpikir dan mengasimilasi dan mengakomodasi konsep, hukum, dan prinsip.

Selanjutnya, sistem penilaian yang digunakan dalam e-LKPD sudah berada pada C4, C5 dan C6. Menurut Anderson dan Krathwohl (2001), level C4, C5 dan C6 adalah kemampuan berpikir tingkat tinggi. Ini berarti sitstem penilaian dalam e-LKPD yang dikembangkan sudah HOTS. Dengan demikian, siswa harus siap untuk berpikir kritis, logis, reflektif, metakognitif, dan kreatif dalam menjawab soal-soal yang ada dalam e-LKPD (King et al, 2010).

$$
\begin{aligned}
& \text { E-LKPD juga terkategori sangat valid } \\
& \text { dalam hal kesesuaian dengan }
\end{aligned}
$$
karakteristiks siswa. Menurut Jatmika (2005), anak sekolah dasar senang pada sesuatu yang dinamis atau bergerak dan cenderung menyukai beragam aktivitas. Dalam e-LKPD, hal ini direalisasikan dengan menyajikan materi pelajaran dalam bentuk video dan gambar-gambar yang berhubungan dengan materi pelajaran. Selain itu, pendekatan saintifik yang digunakan memberikan beragam aktivitas dan pengalaman belajar bagi siswa. Hal ini tentu tidak membuat mereka merasa bosan selama belajar.

Dalam hal, memberikan umpan balik, e-LKPD terkategori sangat valid. Ini menunjukan bahwa e-LKPD dapat memberikan umpan balik bagi proses belajar siswa. Sadiman (2010) menyatakan beragam retensi belajar siswa dalam menyerap dan memahami penyajian konten pembelajaran yang menyebabkan desain pembelajaran harus dirancang semenarik mungkin agar ada balikan dari siswa. penyajian e-LKPD yang sesuai karakteristik siswa ternyata mampu membuat siswa aktif bertanya kepada guru tentang pelajaran. 
E-LKPD juga terbukti valid dalam memotivasi siswa belajar. Ariana (2010) mengatakan bahwa pembelajaran menggunakan multimedia akan lebih menarik, interaktif, jumah waktu mengajar dengan ceramah dapat dikurangi. Sikap, perhatian belajar siswa ditingkatkan dan dipusatkan, serta kualitas belajar dapat termotivasi. $\mathrm{Di}$ tengah derasnya perkembangan dunia digital, tentu harus dapat dioptimalkan oleh guru sebagai media pembelajaran agar pembelajaran menjadi menarik dan interaktif bagi siswa.

E-LKPD adalah media pembelajaran untukmembantu siswa belajar. Sebagai media pembelajaran, e-LKPD berbasis HOTS yang dikembangkan terkategori sangat valid. Kelima indikator yang dikembangkan (desain presentasi, interaksi penggunaan, aksesebilitas, penggunaan kembali dan memenuhi standar) juga terkategori sangat valid. Ini berarti e-LKPD sangat layak digunakan sebagai media pembelajaran.

Dilihat dari desain, e-LKPD mengkombinasikan video, gambar dan narasi berupa kata-kata. Hal ini membuat siswa menjadi tertarik dalam penggunaannya. Selain itu, dengan mengembangkannya secara elektronik, tentu menghemat waktu guru menjelaskan. Hal ini karena materi sudah dijelaskan secara langsung dalam bentuk video.

Dalam hal interaksi pengguna, eLKPD dilengkapi dengan petunjuk agar mudah menjalankan e-LKPD. Selain itu, aplikasi yang digunakan juga tidak terlalu berat dan maudah diakses. Hal ini menyebabkan siswa dapat menggunakan smartphone untuk mengaksesnya karena ukuran dile yang tidak besar. Sementara itu, tampilan fitur-fitur lain dibuat dengan sangat jelas, seperti langkah-langkah pembelajaran. Hal ini terkait juga dengan aksesabilitas. Dengan menggunakan liveworksheet tentu mudah diakses oleh siswa sekolah dasar.

E-LKPD juga terkategori sangat valid pada aspek penggunaan kembali. E-LKPD dapat diadaptasikan pada tema-tema yang lain. Guru hanya perlu menyesuikan materi pembelajaran, tujuan pembelajaran dan jenis asesmen yang digunakan.
Sementara formatnya yang lain guru harus berusaha menyesuikannya. Pengguna atau guru juga dapat memodifikasinya dengan menambahkan sistem penilaian yang lain. Sepanjang e-LKPD yang disusun sesuai dengan standar yang ditetapkan.

Hasil penelitian ini sejalan dengan penelitian yang dilakukan oleh Muzayyanah, Wijayanti dan Ardiyanto (2020). Hasil uji kevalidan mendapatkan skor ratarata persentase keidealan dari ahli media $85,66 \%$ dengan kriteria "sangat layak" dan dari skor rata-rata persentase keidealan dari ahli materi sebesar $85,75 \%$ dengan kriteria "sangat layak". Sedangkan uji kepraktisan mendapat skor persentase keidealan hasil respon guru sebesar $91,50 \%$ dengan kriteria "sangat layak" dan dari skor rata-rata persentase keidealan hasil respon siswa sebesar 93,41\% dengan kriteria "sangat layak". Dapat disimpulkan bahwa lembar kerja peserta didik yang dikembangkan oleh peneliti valid dan praktis digunakan untuk siswa kelas IV sekolah dasar.

Hasil penelitian lain adalah yang dilakukan oleh Khairani, Susi dan Arlina (2021). Berdasarkan hasil validasi, pengembangan lembar kerja peserta didik berbasis Higher Order Thinking Skill (HOTS) pada pembelajaran matematika untuk kelas IV SD dihasilkan memenuhi kriteria valid dengan persentase penilaian sebesar $83 \%$. Jadi, dapat disimpulkan bahwa lembar kerja peserta didik berbasis Higher Order Thinking Skill (HOTS) pada pembelajaran matematika untuk kelas IV SD valid digunakan sebagai salah satu bahan ajar pembelajaran.

\section{Kepraktisan E-LKPD berbasis HOTS}

Uji kepraktisan e-LKPD melibatkan 3 guru kelas IV. Hasilnya dapat disajikan sebagai berikut.

Tabel 5. Hasil Uji Kepraktisan

\begin{tabular}{llll}
\hline No & Aspek & Nilai & Kategori \\
\hline 1 & Kemudahan & 4,67 & Sangat Praktis \\
2 & Kegunaan & 4,4 & Sangat Praktis \\
3 & Daya Tarik & 4,47 & Sangat Praktis \\
\hline \multicolumn{2}{l}{ Rata-rata } & 4,51 & Sangat Praktis \\
\hline
\end{tabular}


Berdasarkan Tabel 5 maka dapat diketahui aspek kemudahan mendapat nilai 4,67 dengan kategori sangat praktis, aspek kegunaan mendapat nilai 4,4 dengan kategori sangat praktis dan aspek daya tarik mendapatkan nilai 4,47 dengan kategori sangat praktis. Secara umum nilai rata-rata kepraktisan e-LKPD adalah 4,51 dengan kategori sangat praktis.

Hasil uji kepraktisan menunjukan bahwa e-LKPD yang dikembangkan terkategori sangat praktis. Secara spesifik, aspek kemudahan, kegunaan dan daya tarik juga terkategori sangat praktis. Hasil ini menunjukan guru tidak mengalami kesulitan atau hambatan dalam menerapkannya. Nieveen (1999) menyatakan kepraktisan dapat dilihat dari pengguna produk. Dalam konteks ini,produk digunakan oleh guru.

Dalam hal kemudahan, e-LKPD berbasis HOTS yang dikembangkan mudah diterapkan bagi para guru. hal ini karena dibuat sederhana lengkap dengan petunjuknya. Penerapan e-LKPD juga tidak memerlukan waktu yang lama dan tenaga yang banyak. Guru hanya meminta siswa mengakses situs yang diberikan untuk menjalankan e-LKPD. Guru hanya memantau hasil belajar siswa saja yang mereka lakukan dengan menjawab soal yang ada. Selain itu, e-LKPD dilengkapi sistem penilaian dengan rubrik penilaiannya.

Dalam hal kegunaan, e-LKPD tentu membantu guru melaksanaan proses pembelajaran yang inovatif. Apalagi di tengah suasana pandemi seperti saat ini. Menggunakan LKPD berbasis elektronik tentu memudahkan guru mengajar dan tentunya juga siswa dalam belajar. Dengan menggunakan e-LKPD tentu sesuai dengan tuntutan jaman dan materi yang diajarkan dalam e-LKPD sudah disesuikan dengan permasalahan saat ini. Hal ini tentu membuat e-LKPD semakin berguna bagi peserta didik dan guru.

Dalam hal daya tarik, e-LKPD dirancang sesuai dengan kebutuhan siswa dan karakteristik siswa. Gambar-gambar yang disajikan mampu memancing rasa ingin tahu siswa karena memang dekat dengan kehidupan sehari-hari siswa. Materi pelajaran juga dirancang sesuai karakteristiks anak sekolah dasar. Ini bertujuan agar pembelajaran tidak terlalu berat bagi siswa yang justru menyebabkan siswa malas menggunakan e-LKPD.

Dengan demikian, e-LKPD berbasis HOTS yang dikembangkan sudah layak digunakan karena bersifat praktis. Menurut Kumalasari (2018), media yang praktis dapat memberikan suasana baru, meningkatkan motivasi belajar siswa, memberikan wawasan yang lebih luas dan mempermudah pemahaman siswa terhadap materi. Ini menunjukan hal yang praktis bagi pengguna membawa dampak yang positif.

Hasil penelitian ini sejalan dengan penelitian yang dilakukan oleh Purwasi dan Fitriyana (2020). Berdasarkan hasil penilaian validasi diperoleh skor rata-rata, yaitu aspek materi sebesar 3,73 dengan kategori valid, aspek konstruksi/media sebesar 4,28 dengan kategori sangat valid dan aspek bahasa sebesar 4,06 dengan kategori valid. Hasil penilaian kepraktisan siswa diperoleh skor rata-rata sebesar 4,15 dengan kategori praktis dan kepraktisan guru sebesar 3,60 dengan kategori praktis. Selanjutnya, hasil penilaian keefektifan melalui tes HOTS menunjukkan persentase ketuntasan secara klasikal sebesar $86,7 \%$ dan respon siswa menunjukkan respon positif terhadap LKPD.

Penelitian lain yang mendukung adalah Khotimah dan Sari (2020). Hasil dari uji kevalidan menunjukkan bahwa LKPD berbasis HOTS memenuhi kriteria kevalidan dengan skor 3,385. Hasil dari uji kepraktisan menunjukkan bahwa LKPD berbasis HOTS memenuhi kriteria kepraktisan dengan skor 3,288. Berdasarkan hasil kevalidan dan kepraktisan dapat disimpulkan bahwa LKPD berbasis HOTS pada materi SPLDV menggunakan konteks lingkungan layak digunakan dalam pembelajaran.

\section{Efektivitas E-LKPD berbasis HOTS}

Hasil uji efektivitas menunjukan bahwa e-LKPD berbasis HOTS yang dikembangkan terkategori sangat efektif. Hal ini dapat dilihat dari nilai rata-rata yang didapat siswa sebesar 83,67 dengan ketuntasan $90 \%$. Nilai ini lebih tinggi dari 
KKM yang ditetapkan sebesar 70 dan ketuntasan klasikal sebesar $85 \%$.

Hasil ini menunjukan bahwa kemampuan berpikir tinggi siswa sudah terbentuk melalui penerapan e-LKPD berbasis HOTS. Pengembangan e-LKPD secara ideal dan mempertimbangkan karakteristiks siswa mampu membentuk kemampuan HOTS siswa. efektivitas eLKPD ini tidak terlepas dari karakteristiks e-LKPD.

Pada aktivitas pembelajaran, eLKPD menerapkan pendekatan saintifik. Dengan menerapkan pendakatan saintifik maka proses pembelajaran membuat pembelajar secara aktif mengonstruk konsep, hukum atau prinsip melalui tahapan-tahapan mengamati (untuk mengidentifikasi atau menemukan masalah), merumuskan masalah, merumuskan hipotesis, mengumpulkan data dengan berbagai teknik, menganalisis data, menarik kesimpulan, dan mengomunikasikan konsep, hukum atau prinsip yang ditemukan (Karar dan Yenice, 2012). Hal ini tentu memfasilitasi siswa berpikir tingkat tinggi karena proses yang dijalani siswa.

Karakteristiks e-LKPD yang dikembangkan juga disesuaikan dengan karakteristiks siswa sekolah dasar. Menurut Heruman (2013), peserta didik sekolah dasar (SD) umumnya berkisar antara 6 atau 7 tahun sampai 12 atau 13 tahun, mereka berada pada fase operasional konkret. Kemampuan yang tampak pada fase ini adalah kemampuan dalam proses berpikir untuk mengoperasikan kaidah-kaidahlogika, meskipun masih terikat dengan objek yang bersifat konkret. Objek konkret tersebut yang dapat ditangkap oleh panca indra. Penggunaan media video dan gambar dalam e-LKPD mampu membuat siswa mengembangkan pemikiran tingkat tingginya karena sesuai dengan karakter mereka.

Hasil penelitian ini sejalan dengan penelitian yang dilakukan oleh Purwasi dan Fitriyana (2020). hasil penilaian keefektifan melalui tes HOTS menunjukkan persentase ketuntasan secara klasikal sebesar $86,7 \%$ dan respon siswa menunjukkan respon positif terhadap LKPD. Hasil penilaian tes menunjukkan rata-rata pretes diperoleh 30,76, sedangkan postes diperoleh 74,09. Artinya, terdapat peningkatan rata-rata nilai kemampuan berpikir tingkat tinggi dari pretes ke postes dalam ujicoba lapangan.

\section{PENUTUP}

Berdasarkan hasil analisis secara deskriptif maka ada empat simpulan yang dibuat,yaitu : a) karakteristiks e-LKPD mencakup 5 bagian, yaitu : komponen, tampilan, materi, aktivitas pembelajaran dan sistem penilaiannya, b) e-LKPDyang dikembangkan terkategori sangat valid baik dari materi maupaun sebagai media pembelajaran, c) e-LKPD yang dikembangkan bersifat sangat praktis dan d) e-LKPD yang dikembangkan sangat efektif.

Berdasarkan simpulan maka ada saran-saran yang diberikan kepada guru dan kepala sekolah. Guru sekolah dasar kelas IV disarankan untuk menggunakan e-LKPD yang dikembangkan khususnya untuk tema "cita-citaku". Hal ini karena eLKPD yang dikembangkan sudah terbukti valid, praktis dan efektif. Guru juga dapat menambahkan latihan soal dalam bentuk essay jika dirasakan penilaian dalam eLKPD masih kurang. Selain itu, guru juga disarankan untuk dapat memahami eLKPD dengan baik sehingga dalam penerapannya tidak menemui halangan. Kepala sekolah disarankan untuk aktif memotivasi guru mengembangkan eLKPD berbasis HOTS. Bila perlu, kepala sekolah mengundang ahli dari instansi terkait untuk membimbing guru mengembangkan e-LKPD berbasis HOTS. Hal ini sebagai upaya untuk merealisasikan tujuan Kurikulum 2013 edisi revisi 2017.

\section{DAFTAR RUJUKAN}

Ahmad, dkk. (2018). Studi Tentang Prestasi Belajar Siswa Dalam Berbagai Aspek Dan Faktor Yang Mempengaruhi. Jurnal Komunikasi Pendidikan. 2(2) : 115-123

Anderson, L.W dan Krathwohl, D.R. 2001. A Taxonomy for Learning, Teaching, and Assesing;A revision of Bloom's Taxonomy of Education Objectives. 
New York: Addison Wesley Lonman Inc

Darmojo, Hendro dan Kaligis, Jenny R.E. 1993. Pendidikan IPA 2.Jakarta: Depdikbud.

Dewi, T. N. C dan Susilowibowo, J. 2016. Pengembangan LKS dalam Rangka Menunjang Pembelajaran Berbasis Scientific Approach pada Materi Laporan Keuangan Perusahaan Jasa. Jurnal Pendidikan, Vol 4(3), hal, 1-6.

Dinni, H., 2018. "HOTS (High Order Thinking Skills) dan Kaitannya dengan Kemampuan Literasi Matematika."PRISMA, Prosiding Seminar Nasional Matematika. 1, 170-176. Hamalik, Oemar. 2001. Proses Belajar Mengajar. Jakarta: Bumi Aksara

Heruman, 2013. Model Pembelajaran Matematika di Sekolah Dasar. Bandung: PT REMAJA ROSDAKARYA.

Hosnan.2014. Pendekatan Saintifik dan Kontekstual dalam Pembelajaran Abad 21. Bogor: Ghalia Indonesia.

Jatmika H. 2005. Pemanfaatan Media Visual dalam Menunjang Pembelajaran Pendidikan Jasmani di Sekolah Dasar. Jurnal Pendidikan Jasmani Indonesia.

Karar, E. E dan Yenice, N. 2012. The Investigation of Scientific Process Skill Level of Elementary Education 8th Grade Students in View of Demographic Features. Procedia Social and Behavioral Sciences, 46, 3885-3889.

Khairani, Khairani., Susi, Herawati and Arlina, Yuza. 2021. Pengembangan Lembar Kerja Peserta Didik (LKPD) Berbasis Higher Order Thinking Skill (Hots) Pada Pembelajaran Matematika Materi Pengukuran Sudut Untuk Peserta Didik Kelas IV SD N 20 Kurao Pagang. Repository Universitas Bung Hatta.

Khotimah, R. P dan Sari, M. C. P. 2020. Pengembangan Lembar Kerja
Peserta Didik Berbasis Higher Order Thinking Skills (HOTS) Menggunakan Konteks Lingkungan. Jurnal Aksioma: Jurnal Program Studi Pendidikan Matematika, Vol 9(3), hal. 761-775.

King,F., Goodson, L., \& Rohani, F. (2011). Higher Order Thinking Skills: Assessment and Evaluation. California, USA: Center for Advandcement of Learning and Assessment.

Kumalasari, Maharani Putri. 2018. Kepraktisan Penggunaan Multimedia Interaktif pada Pembelajaran Tematik Kelas IV SD. Jurnal Bidang Pendidikan Dasar (JBPD), 2(1), 1-11

Musfiqi, S dan Jailani, J. 2014. Pengembangan Bahan Ajar Matematika yang Berorientasi pada Karakter dan Higher Order Thinking Skill (HOTS). Tersedia pada https://journal.uny.ac.id/index.php/py thagoras/article/view/9063

Muzayyanah,A., Wijayanti, A dan Ardiyanto,A. 2020. Pengembangan Lembar Kerja Peserta Didik (LKPD) Tematik Berbasis HOTS (Higher Order Thinking Skill) Kelas IV Sekolah Dasar. Tersedia pada https://jurnalfkip.unram.ac.id/index.p hp/JPM/article/view/1961

Nieveen, N. 1999. Prototyping to Reach Product Quality. Dalam Plomp, T; Nieveen, N; Gustafson, K; Branch, R.M; dan van den Akker, J (eds). Design Approaches and Tools in Education and Training. London: Kluwer Academic Publisher.

Nurjanah, Lia Adisa., Arcana, I Nyoman dan Rhosyida, Nelly. 2019. Pengembangan Lembar Kegiatan Peserta Didik Berbasis Higher Order Thinking Skills pada Materi Skala Kelas V Sekolah Dasar. Trihayu, Vol 5(3), hal. 646-654

Prastowo, Andi. 2014. Pengebangan Bahan Ajar Tematik Tinjauan Teoritis Dan Praktik. Jakarta : Kencana. 
Purwasi, Lucy Asri dan Fitriyana, Nur. 2020. Pengembangan Lembar Kerja Peserta Didik (LKPD) Berbasis Higher Order Thinking Skill (HOTS). Aksioma, Vol 9(4), hal. 894-908

Sadiman, Arief S. 2009. Media Pendidikan. Jakarta : Rajawali Pers

Sudijono, Anas. 2009. Pengantar Evaluasi Pendidikan. Jakarta: Raja grafindo

Suryabrata, Sumadi. 2000. Metode Penelitian. Jakarta: PT. Raja Grafindo Persada

Suyanto, Slamet,dkk. 2011. Lembar Kerja Siswa (LKS).Prosiding Seminar Pembekalan guru daerah terluar, terluar, dan tertinggal Yogyakarta: Universitas Negeri Yogyakarta

Teti dan Hamdu, Ghullam. 2018. Pengembangan Lembar Kerja Siswa Berbasis Hots Berdasarkan Taksonomi Bloom di Sekolah Dasar. Pedadidaktika, Vol 5(3), hal. 45-58

Trianto. (2010). Mendesain Model-Model Pembelajaran Inovatif Progresif. Jakarta: CV Pustaka Cendekia Utama. 